\title{
Menata Kontestasi Simbol-Simbol Keagamaan di Ruang Publik Kota Jayapura
}

\author{
Muhamad Yusuf ${ }^{*}$, Sahudi Sahudi ${ }^{2}$, Marwan Sileuw ${ }^{3}$, Linda Safitri ${ }^{4}$ \\ IAIN Fattahul Muluk Papua, Indonesia, joesoef1974@gmail.com \\ 2 IAIN Fattahul Muluk Papua, Indonesia, tugassahudi15@gmail.com \\ 3 IAIN Fattahul Muluk Papua, Indonesia, marwan.sileuw@yahoo.co.id \\ 4 IAIN Surakarta, Indonesia, lindaasafitri89@gmail.com \\ * Correspondence: joesoef1974@gmail.com
}

Received: 2020-11-12; Accepted: 2021-06-04; Published: 21-08-2021

\begin{abstract}
The freedom to use Christian religious symbols in Jayapura City creates social unrest and jealousy for other people. This article aims to analyze the religious symbols used by Christians, intense contestation of religious symbols by Christians in Jayapura City, and ideas about its arrangement. This qualitative research uses the paradigm of social phenomenology. This study found that Muslims in Jayapura City is the second largest after Protestant Christianity, but religious development is ranked third after Protestant Christianity and Catholicism. Islam is considered the religion of migrants. The rise of Christian religious symbols in Jayapura City as holy people who have majority control and have freedom of expression in religious symbols is carried out by religious groups in other areas and applied in Jayapura City. The role of central government policy is needed to emerge various ideas in the community in the region. Regional regulations provide freedom for the use of religious symbols. The religious majority who control the government sector has control over the use of religious symbols rather than minority groups by making rules that bind religious communities and raise the exclusivity of the majority group. The local parliament members (DPRD)'s inability to realize the aspirations of the Muslim community of Jayapura City is due to the lack of Muslim members of the local parliament (DPRD). Hence, they have limited numbers in supervising emerging policies, including the use of religious symbols.
\end{abstract}

Keywords: Muslim migrants; policy oversight; religious fanaticism; religious symbols; sociology of religion.

\begin{abstract}
Abstrak: Kebebasan penggunaan simbol keagamaan Kristiani di Kota Jayapura menimbulkan keresahan dan kecemburuan sosial bagi umat lainnya. Artikel ini bertujuan untuk menganalisis bentuk simbol keagamaan yang digunakan oleh umat Kristiani; kontestasi simbol keagamaan yang kental oleh umat Kristiani di Kota Jayapura; dan gagasan tentang penataannya. Penelitian kualitatif ini menggunakan paradigma fenomenologi sosial. Kajian ini menemukan bahwa keberadaan umat Muslim di Kota Jayapura merupakan peringkat kedua terbesar setelah Kristen Protestan, namun pengembangan keagamaan dinomortigakan setelah Kristen Protestan dan Katholik. Agama Islam dianggap sebagai agama kaum migran. Maraknya simbol keagamaan Nasrani di Kota Jayapura sebagai umat keagamaan yang mayoritas menguasai dan memiliki kebebasan berekspresi dalam penggunaan simbol keagamaan, akibat peniruan yang dilakukan oleh kelompok keagamaan di daerah lainnya dan diterapkan di Kota Jayapura. Peran kebijakan pemerintah pusat dibutuhkan terhadap munculnya berbagai ide dalam masyarakat di daerah. Aturan daerah memberikan keleluasaan penggunaan simbol keagamaan, mayoritas keagamaan yang menguasai sektor pemerintahan berkuasa atas penggunaan simbol keagamaan ketimbang kelompok minoritas dengan membuat aturan yang mengikat komunitas keagamaan, dan memunculkan eksklusivitas kelompok mayoritas. Ketidakmampuan Dewan Perwakilan Rakyat Daerah (DPRD) dalam merealisasikan aspirasi masyarakat Muslim Kota Jayapura disebabkan kurangnya jumlah anggota DPRD Kota Jayapura yang beragama Muslim, sehingga memiliki keterbatasan jumlah dalam mengawasi kebijakan yang muncul termasuk penggunaan simbol keagamaan.
\end{abstract}


Kata Kunci: Fanatisme keagamaan; migran muslim; pengawasan kebijakan; simbol keagamaan; sosiologi agama.

\section{Pendahuluan}

Kota Jayapura yang merupakan ibu Kota propinsi Papua rawan munculnya konflik yang berkaitan dengan Suku dan Agama. Untuk berbagai konflik yang berkaitan dengan kesukuan dirasakan masih dalam skala kecil, namun sangat dikhawatirkan adalah yang berkaitan dengan agama, di mana benih perpecahan mulai nampak dengan munculnya fanatisme keagamaan di kalangan umat beragama. Keberadaan umat Muslim di Kota Jayapura berada di peringkat kedua terbesar setelah Kristen Protestan, namun dalam berbagai hal umat Muslim dinomortigakan oleh pemerintah daerah, berbagai aturan yang mengekang untuk dapat melakukan syiar keagamaan, Islam dianggap sebagai agama para pendatang. Orang asli Papua dominan beragama Protestan, penyebarannya dilakukan oleh Zending dan Misionaris yang aktif si'arnya sampai pelosok Papua. Berbagai kegiatan berkaitan dengan agama kaum pribumi yaitu agama Kristen, kemeriahan dilaksanakan sesuka hati tanpa pembatasan yang dilakukan pemerintah daerah, terlebih dalam menyambut Natal dan Tahun Baru Masehi, berbagai simbol agama Kristiani sangat kental mulai dari salib di atas gunung, salib di Kayu Pulau pintu masuk Kota Jayapura, salib di gang perumahan, bahkan di depan pintu pagar mesjid, lampu bercirikan lilin Natal di sepanjang jalan, pohon Natal menghiasi sudut Kota, khotbah keagamaan dilakukan di pondok Natal dengan speaker yang sanggup terdengar hingga kiloan meter dilakukan dari terbenamnya matahari sampai terbitnya fajar. Begitu pula, pertokoan dihiasi dengan pernak-pernik Kristen, dan para pelayan toko yang beragama Islam pun diwajibkan menggunakan pernak-pernik Natal. Pondok Natal yang dibangun disponsori oleh Pemerintah Daerah, dan terdapat penilaian dengan hadiah yang ditawarkan oleh Pemda. Sebaliknya, ketika perayaan Idul Fitri tidak semeriah perayaan Natal. Jangankan menghias jalan, takbir keliling tidak dilaksanakan, sementara perayaan Natal dan Tahun Baru, sekolah diliburkan lebih dari 2 minggu oleh Pemda.

Rentan munculnya disintegrasi yang diakibatkan faktor keagamaan, di mana penduduk asli Kota Jayapura menganggap pendatang Muslim tidak sama dengan mereka yang beragama Kristiani, sehingga dapat menimbulkan gesekan antar warga yang berbeda agama, terlebih dengan kontestasi simbol yang marak dilakukan kaum Kristiani menimbulkan keresahan kaum Muslim, sedangkan umat Islam tidak melakukan kontestasi yang berlebihan dalam penggunaan simbol keagamaan. Kebebasan yang diberikan Pemda secara berlebihan dapat menimbulkan gesekan antar umat beragama terlebih dengan masuknya faham radikalis baik di kalangan Kristiani maupun Islam, yang tidak menginginkan kedamaian di antara umat beragama di Kota Jayapura, di mana jumlah yang berimbang dapat menimbulkan gesekan yang ditimbulkan akibat munculnya kecemburuan sosial akibat penggunaan simbol keagamaan yang berlebihan. Apakah ini merupakan syiar keagamaan yang dilakukan oleh umat Kristiani sehingga memaksa Muslim melihat kebesaran mereka di Kota Jayapura? Berbagai fenomena yang terjadi meresahkan umat Muslim dan mengkhawatirkan. Untuk itu dibutuhkan ketegasan dari Pemerintah dalam penggunaan berbagai simbol keagamaan dengan menerapkan berbagai peraturan yang tidak diskriminatif. Artikel ini bertujuan untuk mengetahui tentang bentuk simbol keagamaan yang digunakan oleh umat Kristiani di Kota Jayapura dan akibat yang ditimbulkannya; tentang bagaimana kontestasi simbol keagamaan yang kental oleh umat Kristiani di Kota Jayapura; serta bagaimana menatanya.

Penelitian sebelumnya yang pernah dilakukan adalah sebagai berikut. Qodir, (2015) mengatakan bahwa kontestasi antara orang asli Papua yang merupakan penganut Kristen dengan sebutan orang gunung dengan orang pantai yang beragama Islam yang dianggap bukan orang Papua. Kontestasi terjadi di ruang publik mulai dari jalan, gunung, lapangan, serta berbagai kegiatan keagamaan dengan mengerahkan massa baik yang dilakukan oleh kelompok Muslim maupun Kristiani dengan mendatangkan pemuka agama dari luar Papua agar menjadi daya tarik tersendiri. Terkadang menimbulkan benturan dalam kegiatan keagamaan baik secara internal maupun eksternal.

Faisal (2019) menegaskan bahwa para pendatang Muslim melakukan berbagai upaya dalam mengatasi berbagai kendala di era Otonomi Khusus Papua melalui tiga cara. Pertama, pendatang 
Muslim memperkuat ekonomi khususnya sektor informal, Kedua tidak dijadikannya sektor politik sebagai tujuan utama keberadaan pendatang Muslim, ketiga, pendatang Muslim tidak bersikap istimewa khususnya dalam membangun komunikasi dengan orang asli Papua. Iribaram (2018) menjelaskan terdapat diskriminasi terhadap umat Muslim di Papua dalam penentuan pejabat di birokrat khususnya di Kota Jayapura walaupun terhadap orang asli Papua yang beragama Islam. Dijelaskan pula Otonomi Khusus yang digulirkan bukan hanya memiliki dampak sentiment kedaerahan yang kuat, tetapi juga berdampak pada kelompok keagamaan khususnya Muslim. Hal ini berakibat pada penentuan jabatan dalam birokrasi di Kota Jayapura.

Jubba (2020) mengatakan kontestasi simbol di Kota Jayapura bukan hanya merupakan bentuk perlawanan terhadap agama lain, akan tetapi juga merupakan keprihatinan sejarah. Kajian ini lebih mengarah pada factor ekonomi dan politik. Artikel tersebut memiliki perbedaan dengan artikel ini, di mana lebih ditekankan pada penggunaan simbol secara berlebihan di berbagai sudut Kota Jayapura yang tidak pada tempatnya, tidak adanya aturan tentang penggunaan simbol keagamaan sehingga penggunaan simbol keagamaan dilakukan secara berlebihan oleh satu kelompok keagamaan. Di mana Kota Jayapura rentan perpecahan yang diakibatkan gesekan antara agama akibat berimbangnya jumlah penganut Islam dan Kristiani. Tidak menyebutkan istilah orang pantai dan orang gunung, karena umat Kristiani juga banyak yang merupakan orang pantai yang merupakan orang asli Papua. Sedangkan orang gunung hanya diperuntukkan bagi mereka yang berasal dari pedalaman atau pegunungan di Papua, serta penggunaan teori simbol dan identitas dan teori agama dalam menganalisis.

Emile Durkheim yang dikutip Ghazali (2011, p. 7) mengatakan: "Bentuk primitif dari sosiologi adalah agama. Agama merupakan sumber tatanan sosial serta juru tafsir tatanan sosial". Durkheim dalam Nawir (2020, p. 5) mengatakan: "Masyarakat yang merupakan sumber agama. Durkheim beranggapan agama merupakan sebuah sistem kepercayaan". Durkheim yang dikutip Turner (2012, p. 698), "Agama tetap merupakan sebuah fakta sosial, sebuah kenyataan sosial yang tidak mungkin dibantah oleh ilmu pengetahuan, atau dapat dikatakan agama akan beradaptasi serta merubah diri sendiri serta tidak akan menghilang". Weber yang dikutip Bataona \& Bajari (2017, p. 122) mengatakan: "Meski terdapat perbedaan antara agama dengan politik, namun pada masalah kekuasaan, keduanya memiliki persamaan bahkan sering memperlihatkan yang erat".

Langer dan Geertz dalam Dillistone (2002, p. 116) mengatakan: "Setiap objek, peristiwa, sifat, hubungan atau tindakan, yang memiliki peran untuk wahana sebuah konsepsi, di mana konsepsi tersebut merupakan "makna" simbol. Dengan demikian menafsirkan kebudayaan pada intinya adalah menafsirkan simbol-simbol". Macionis yang dikutip Samovar (2010, p. 46), mengatakan, "Simbol adalah segala hal yang berkaitan dengan makna khusus yang dipahami oleh orang-orang yang menyebarkan budaya". Menurut Erwin Goodenough dalam Hasbullah (2011, p. 18), mengatakan: "Simbol merupakan pola atau barang yang dalam sebab apapun, aktivitas dalam manusia, melebihi pengakuan semata-mata mengenai sesuatu yang ditampilkan secara harafiah dalam wujud yang diberikan". John A. Saliba yang dikutip Sari $(2018$, p. 2) mengatakan: "Simbol merupakan suatu bentuk komunikasi yang ekspretif, memiliki sebuah informasi atau pesan yang tidak mampu diucapkan secara langsung, Simbol dapat berimplikasi makna yang tidak berasal dari pengalaman, karena simbol merujuk pada realitas yang lain diluar konteks pengalaman". Gary Fine yang dikutip Turner (2012, p. 650) mengatakan: "Kelompok-kelompok kecil mengembangkan serangkaian makna (keyakinan, pengetahuan, serta kebiasaan), yang unik yang merupakan dasar pemahaman bersama serta melakukan pengembangan interaksi dan tindakan selanjutnya". Menurut Appadurai dalam Ernas (2015, p. 7) mengatakan: "Aktor politik lokal yang berkuasa merupakan subjek yang selalu melakukan propaganda untuk memberikan warna, citra serta makna terhadap sebuah simbol yang merupakan komoditi yang ditawarkan pada masyarakat luas".

Dahrendorf yang dikutip Ritzer \& Goodman (2012, pp. 156-157) mengatakan: “Konsep kepentingan terselubung, kelompok semu, kelompok kepentingan, kelompok konflik serta kepentingan nyata, merupakan konsep mendasar agar menerangkan konflik sosial. Di bawah keadan yang ideal tidak terdapat lagi variabel lain yang dibutuhkan. Namun sebab keadaan tidak pernah ideal, 
maka banyak faktor lain turut berpengaruh pada proses konflik sosial". Freud yang dikutip (2012, pp. 90-91) mengatakan: "Ketegangan serta tekanan yang kemudian timbul melalui adanya dorongandorongan tersebut juga berbeda-beda. Mereka biasanya terlibat pada konflik ketika berbenturan satu dengan lainnya atau ketika berhadapan dengan realita dari dunia luar yang tidak dapat dirubah. Collins yang dikutip Ritzer \& Goodman (2012, p. 163) mengatakan: "Saat orang lain selalu mencoba mengontrol orang yang menentang mereka, akibatnya adalah memungkinkan timbulnya konflik di antara individu".

Politik identitas adalah partisipasi individu dan lebih ditentukan oleh budaya dan psikologis seseorang. Jika proses terbentuknya pada kondisi tertekan (identitas resistensi) melalui munculnya dominasi pihak lain, maka akan timbul identitas dalam istilah Calhoun politik identitas (Castells, 2011). Buchari (2014, p. 24) mengatakan: "Politik identitas merupakan alat perjuangan politik suatu etnis agar tercapai tujuan yang telah ditentukan, di mana munculnya lebih dipengaruhi adanya faktor tertentu yang dianggap oleh suatu etnis merupakan tekanan dalam bentuk ketidak-adilan politik yang dialaminya. Akibat tekanan yang ada, mereka bangkit melakukan perlawanan dengan identitas yang dimiliki agar melawan berbagai bentuk ancaman, termasuk penindasan (baik fisik maupun non-fisik)". Parsudi Suparlan dikutip Nawir (2020, p. 7) mengatakan: "Identitas atau jati diri itu muncul dan ada dalam interaksi. Seseorang memiliki jati diri tertentu karena adanya pengakuan keberadaannya oleh orang lain dalam suatu hubungan yang berlaku. Sedangkan Politik Identitas adalah partisipasi individual pada kehidupan sosial yang lebih ditentukan oleh budaya dan psikologis seseorang". Identitas adalah proses konstruksi dasar dari budaya serta psiko-kultural dari individu yang memberi arti serta tujuan hidup dari individu tersebut, karena terbentuknya identitas dari proses dialog internal dan interaksi sosial. Lebih lanjut dijelaskan: identitas memiliki peran dalam bentuk kekuatan bagi orang di mana identitas tersebut melekat (Castells, 2011).

Merupakan penelitian deskriptif kualitatif. Logika berfikir asumsi inter-subjektif, paradigma penelitian kualitatif menggunakan paradigma fenomenologi sosial (Denzin Yvonna S., 2009) model studi kasus intrinsik. Menggunakan sumber data primer yaitu data yang langsung dikumpulkan peneliti dari sumber pertamanya dengan cara memperoleh informan atau subyek yang akan diteliti, yaitu umat Islam di Kota Jayapura, para Ulama, dan Anggota DPRD Kota Jayapura. Setting penelitian ini adalah Kota Jayapura, Papua. Narasumber kunci dalam penelitian adalah masyarakat Kota Jayapura, para ulama, anggota DPRD Kota Jayapura, serta peneliti sendiri. Mendapatkan data lapangan dengan observasi partisipatoris yang pasif dan in-depth interview. Teknik analisa data yang digunakan adalah dengan membagi ke dalam tiga bagian, yaitu melakukan reduksi data, display data, dan verifikasi serta kesimpulan.

\section{Keyakinan dan Nilai-nilai Keagamaan Kristiani}

Umat Kristiani di Kota Jayapura berusaha mengembangkan keagamaannya melalui simbol keagamaan, dapat dilihat dari berbagai bentuk simbol keagamaan yang terpampang di berbagai sudut Kota Jayapura mulai dari Salib yang dihiasi dengan kain berwarna ungu, bintang Daud, pohon Natal di depan kantor pos Abepura (gambar 1), pondok Natal, lilin, gambar replika Yesus Kristus dalam bentuk kecil dan besar yang dapat dilihat dari kejauhan, dan banyak lagi bentuk simbol keagamaan digunakan yang menghiasi sudut Kota Jayapura. Salah satu simbol keagamaan yang tidak lazim dilaksanakan adalah orasi keagamaan yang dilakukan oleh orang perorang dipinggir jalan. Simbolsimbol keagamaan biasanya dibuat tiga minggu sebelum dilaksanakannya hari besar keagamaan baik Natal, Paskah, dan Tahun Baru Masehi, bahkan sebulan sebelum perayaan, dan simbol tersebut terkadang dibiarkan terpasang hingga berbulan-bulan setelah dilangsungkannya hari besar keagamaan, kecuali yang dibuat secara permanen yang tidak dapat dilepas atau dicabut. Simbolsimbol yang bersifat permanen mulai banyak terpajang di sudut Kota Jayapura yang dapat dilihat oleh siapapun yang melintas, karena kebanyakan ditempatkan di pusat keramaian, seperti di depan perkantoran, di pinggir jalan protokol, di depan rumah masyarakat, di mobil dan tempat strategis lainnya, yang tidak kalah pentingnya adalah kegiatan orasi keagamaan di pinggir jalan dekat dengan kantor Polsek Abepura Jayapura, di mana simbol yang menjadi medianya adalah manusia yang 
merupakan simbol yang sangat kuat dan nyata, karena kekuatan simbol yang timbul baik dari gerak tubuh, suara, isyarat, terlebih jika dilakukan dengan pengeras suara, menimbulkan efek yang luar biasa.

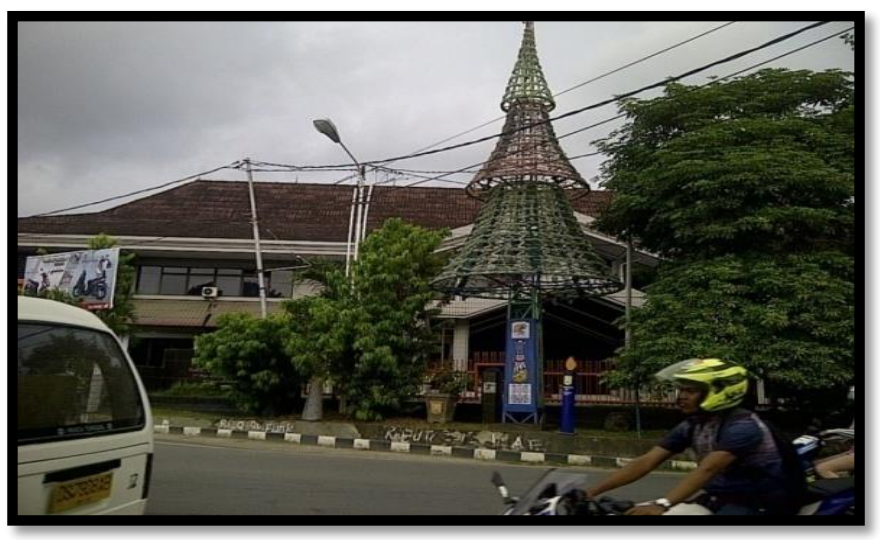

Gambar 1 Pohon Natal Yang Terpasang Secara Permanen di Depan Kantor Pos Wilayah Abepura Jayapura, di Jalan Protokol Jayapura-Abepura-Sentani

Berbagai bentuk simbol keagamaan Kristiani yang ada di Kota Jayapura, mulai dari lilin Natal, bintang Daud, pondok Natal, gambar Yesus Kristus, pohon Natal dan lain sebagainya yang memiliki arti dan makna tersendiri dari setiap simbol yang ada serta merupakan wahana yang dapat ditafsirkan oleh pengikutnya dari setiap simbol yang ada, yang diharapkan mampu memberikan nilai religius pada pengikutnya, di mana simbol keagamaan merupakan identitas dari seseorang atau sekelompok orang yang memiliki peran kekuatan penting bagi sekelompok orang di mana mereka berada.

\section{Simbol dan Makna Keagamaan Kristiani}

Dibutuhkan berbagai kerjasama dari berbagai stakeholder yang ada di Kota Jayapura baik stakeholder primer maupun sekunder untuk memahami dan saling menjaga toleransi antar umat beragama, sehingga disintegrasi bangsa yang disebabkan karena pertikaian antar agama dapat diredam sedini mungkin, di mana diharapkan berlaku netral pada setiap komunitas keagamaan yang ada di Kota Jayapura, sehingga tidak menimbulkan riak-riak perpecahan di antara komunitas keagamaan yang ada. Yang terjadi saat ini di Kota Jayapura adalah sebaliknya, di mana pemerintah daerah lebih memfasilitasi dan mendukung penuh penggunaan simbol-simbol Kristiani di Kota Jayapura, sehingga semakin lama semakin banyak simbol keagamaan yang terpampang di berbagai sudut Kota tanpa menghiraukan tempat dan waktu yang tepat dalam pemasangannya serta tanpa pembatasan dalam penggunaannya, misalnya gambar Yesus Kristus yang terpampang pada tembok (gambar 2). Terlebih ketika dilaksanakannya hari besar keagamaan seperti Natal, Paskah, dan tahun baru Masehi, pemasangan simbol keagamaan terkadang dipasang di depan rumah warga yang beragama non Kristiani, bahkan di depan pintu halaman Mesjid, juga di kantor-kantor pemerintah yang bukan menaungi keagamaan tertentu. Hal ini sangat meresahkan warga yang berbeda keyakinan.

Pemasangan simbol keagamaan yang dilakukan segolongan kelompok keagamaan dilakukan secara terencana dan terkoordinir secara matang, nampak jelas bahwa ini merupakan perang simbol yang sengaja dimunculkan untuk menarik simpatik masyarakat yang memiliki kesamaan keimanan untuk dapat bersatu, sehingga menampakkan kebesaran dalam suatu perbedaan, hal ini disebabkan karena merupakan sesuatu yang terstruktur yang membentuk jaringan kognitif dari skema tindakan yang terkoordinasi. Hal tersebut sejalan dengan pendapat Berger yang dikutip Solikhati (2018, p. 8) yang mengatakan: "Simbol keagamaan selalu memiliki kekuatan dalam mengarahkan pikiran manusia". Untuk itu dibutuhkan ketegasan pemerintah daerah untuk memberikan pembatasan dalam penggunaan simbol keagamaan tanpa membeda-bedakan agama, yang dituangkan dalam aturanaturan yang jelas, serta memberikan ruang khusus atau tempat yang khusus dalam meletakkan 
berbagai simbol keagamaan yang ada sehingga tidak mengganggu umat-umat beragama lainnya di Kota Jayapura.
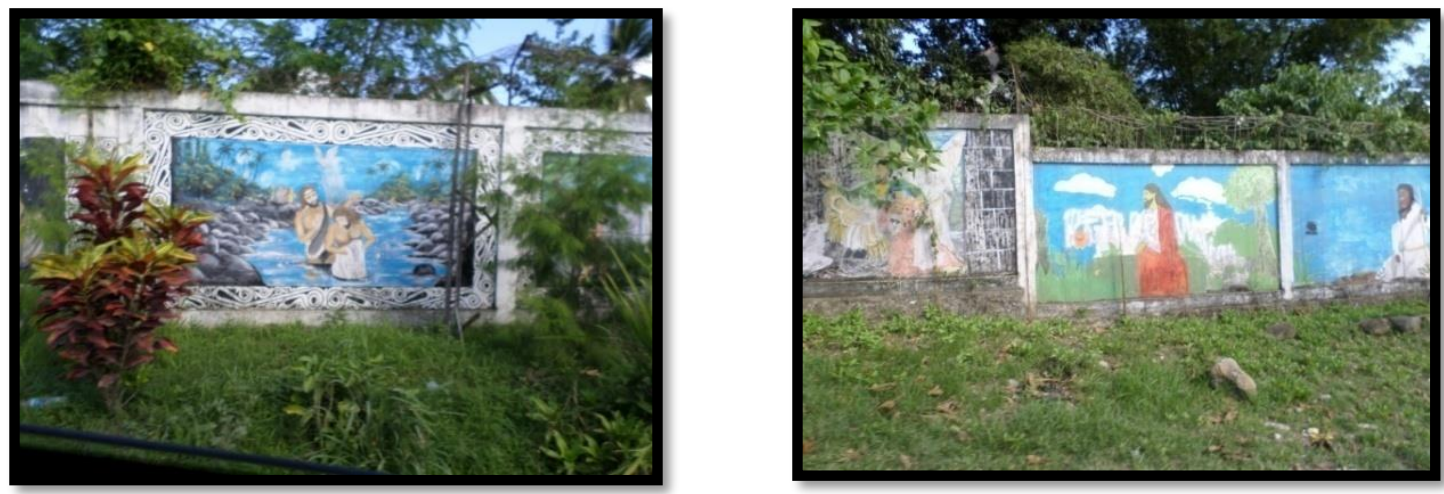

Gambar 2 Gambar Yesus Kristus di Sepanjang Tembok Pagar Pembatas

\section{Pengaruh Simbol Keagamaan Kristiani Pada Umat Muslim}

Penggunaan simbol keagamaan dalam rangka perayaan hari besar kegamaan khususnya Kristiani dirasakan berlebihan hal ini bisa dilihat dari penggunaan simbol keagamaan yang dilakukan oleh pemilik swalayan terhadap para pelayan toko ataupun swalayan, di mana para pelayan swalayan diharuskan menggunakan simbol-simbol keagamaan Kristiani biasanya berupa topi-topi Santa Clauss (gambar 3). Sangat miris ketika pelayan tersebut berjilbab dan menggunakan atribut tersebut maka akan menimbulkan berbagai persepsi di kalangan umat Islam, terlebih pada kelompok garis keras. Hendaknya penggunaan simbol keagamaan tidak melibatkan umat lainnya sehingga tidak terjadi gesekan di antara umat beragama.
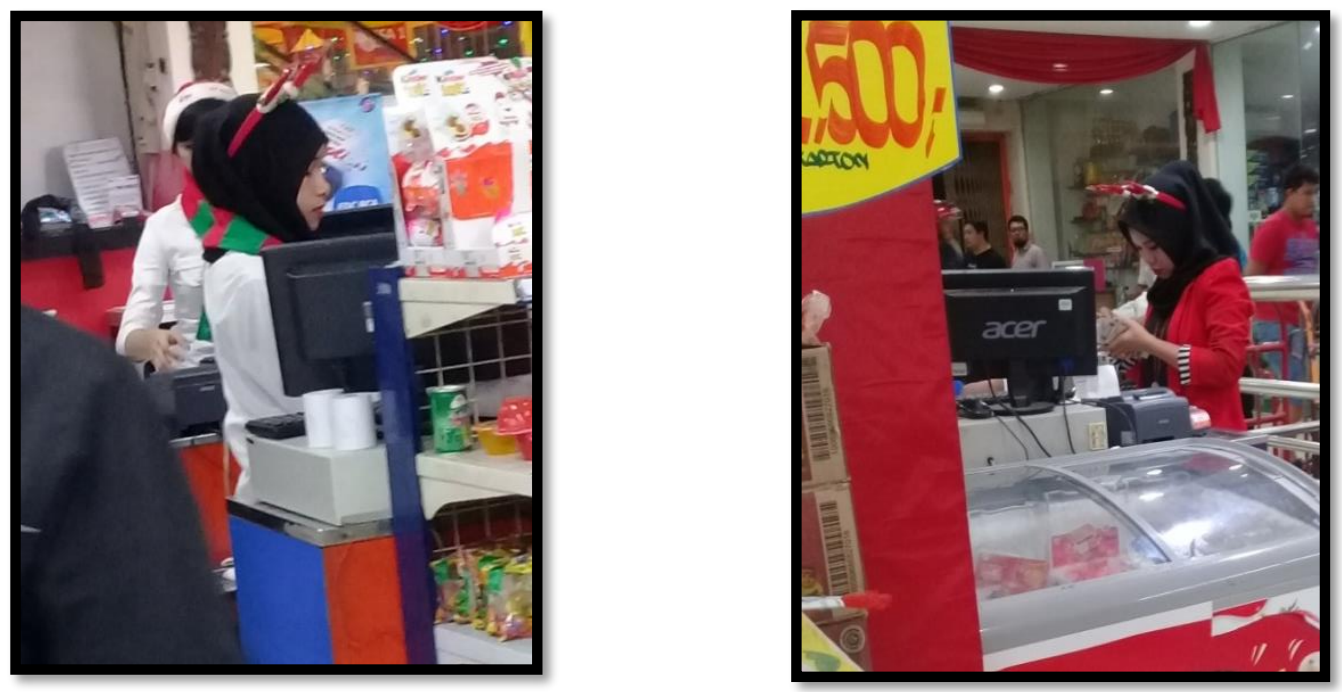

Gambar 3 Penggunaan Simbol Keagamaan Umat Lain Terhadap Umat Islam

Penggunaan simbol keagamaan umat lain terhadap umat Islam tidak harus dicemaskan, karena bukan sesuatu yang harus diimani oleh umat Muslim, akan tetapi hanya untuk menghormati kaum yang lain, namun dengan adanya fatwa MUI tentang pelarangan ini, maka suka atau tidak suka akan diikuti dan dilaksanakan umat Islam pada umumnya termasuk Umat Islam yang ada di Kota Jayapura, karena fatwa MUI berpengaruh terhadap berbagai aktifitas umat Muslim di Indonesia. Terlebih terdapat kelompok dalam Islam yang tidak menginginkan pemaksaan penggunaan simbol keagamaan lain kepada umat Islam. Hal ini sejalan dengan yang diungkapkan Rosalina yang dikutip Saprillah (2020, p. 4) yang mengatakan: "Kemunculan kelompok salaf yang mendapatkan perlawanan dari 
kelompok Islam yang telah ada sebelumnya (NU serta Muhammadiyah), dinamika keagamaan yang berjalan hangat dengan keberadaan kelompok salaf Roja yang secara terus menerus melaksanakan dakwah puritanistik". Di mana mereka mulai berkembang dalam jumlah yang cukup banyak di Kota Jayapura akibat dari pesatnya arus transportasi dari dan menuju Kota Jayapura, maka akan berdampak memudarnya kerukunan antar umat beragama yang ada di Kota Jayapura. Walaupun dari satu sisi ini hanya merupakan kepentingan pemilik supermarket atau toko untuk dapat menarik para pembeli, tetapi dapat membahayakan jika tidak disikapi secara arif dan bijaksana oleh pemilik supermarket atau pemilik toko sehingga dapat merugikan supermarket atau toko itu sendiri.

\section{Dampak Simbolik Keagamaan Kristiani}

Akibat yang ditimbulkan dengan bermunculannya simbol keagamaan secara berlebihan di Kota Jayapura dapat dibagi kedalam beberapa bagian berikut ini.

\section{Kesenjangan antar komunitas keagamaan}

Akibat dari munculnya simbol-simbol keagamaan yang berlebihan menimbulkan keresahan kalangan umat Islam di Kota Jayapura, di mana umat Islam merasa sebagai masyarakat kelas II di Kota Jayapura, karena penggunaan simbol keagamaan secara besar-besaran seolah tengah diadakan Show of Power, sehingga mampu menimbulkan tekanan dalam diri pribadi umat Islam. Kebencian itu merambat dari soal agama ke soal lainnya seperti pendidikan, ketenaga kerjaan, dan lain sebagainya di mana di Kota Jayapura lebih mengutamakan orang asli Papua dan otomatis beragama Kristiani.

Munculnya simbol-simbol keagamaan di mana secara psikologis simbol sangat berpengaruh dalam konteks identitas dari kelompok keagamaan dengan memperlihatkan dan mengembangkan berbagai simbol keagamaan, di mana secara politis mereka memperlihatkan eksistensinya, ini diakibatkan dari mayoritas kelompok keagamaan yang merasa terancam dengan semakin berkembangnya minoritas, di mana di dalam kelompok mayoritas terdapat degradasi dalam penguatan keagamaan pada komunitasnya, sehingga memunculkan gerakan yang terorganisir dilakukan oleh mayoritas yang secara tidak langsung untuk memperkuat keutuhan mereka disamping itu secara tidak langsung menekanan minoritas dengan jalan penggunaan simbol keagamaan secara berlebihan oleh kelompoknya, dengan harapan memperoleh dukungan yang besar dari pengikutnya, tetapi ketika hal tersebut tidak dapat dibatasai dan diatur dengan baik dan benar, serta tidak dapat dihindari keberadaaannya secara berlebihan, maka dapat menimbulkan konflik ketika bertabrakan satu sama lain antara kelompok keagamaan yang ada di Kota Jayapura. Penggunaan simbol keagamaan yang berlebihan, dapat ditunggangi oleh kelompok kepentingan (interest group) yang memiliki kepentingan tertentu untuk mencapai tujuan yang diinginkannya.

\section{Bermunculan kelompok fanatisme keagamaan}

Kelompok-kelompok fundamentalis yang ada di Kota Jayapura memang tidak sebanyak yang ada di Kota lainnya di Indonesia, namun jika ini dibiarkan, dapat menjadi pemicu munculnya pertikaian antar umat beragama. Di mana mereka antipati terhadap kelompok keagamaan lainnya, bahkan terhadap kelompoknya sendiri yang berseberangan dalam hal ibadah. Kelompok ini sangat fanatik terhadap agama yang dianutnya. Kelompok tersebut merasa diri mereka paling benar dari yang lainnya dan menganggap yang lainnya salah dalam beribadah. Kelompok ini sangat antipati terhadap penggunaan simbol-simbol keagamaan orang lain yang berbeda akidah, dan bukan hanya itu mereka terkadang menghasut untuk dapat memecah belah kedamaian di manapun mereka berada, sehingga jiwa-jiwa yang tadinya tanpa adanya rasa permusuhan, semakin lama semakin terhasut, sehingga menimbulkan kebencian yang mendalam di kalangan umat beragama. Kelompok-kelompok ini biasa disebut dengan istilah kelompok radikal, fundamental, militant ekstremis, atau revivalis. Bagi kelompok tersebut, di mana agama sering dijadikan alasan pembenar. Hal ini sejalan dengan yang dikatakan Baso dalam Lutfi (2019, p. 25) mengatakan, "Adanya keterkaitan di antara kuasa serta pengetahuan agama dan menjadikannya bagian integral dari cara "berkuasa serta menguasai", yang 
pada akhirnya menghasilkan sikap dari pemeluk agama tersebut mempunyai "kehendak menjadi benar".

Sifat fanatisme muncul dalam diri setiap orang beragama, karena setiap agama memiliki keyakinan akan kebenaran ajarannya sehingga memunculkan benih fanatisme yang dianggap mampu untuk membentengi umat beragama dalam kehidupan nyata, tetapi ketika fanatisme itu dilaksaksanakan secara berlebihan maka berdampak pada disintegrasi bangsa hal ini dikarenakan masalah yang berkaitan dengan primodialisme rentan terhadap perpecahan, terlebih yang berkaitan dengan agama. Hal tersebut seperti yang diungkapkan Bertrand yang dikutip Setyawati (2010) mengatakan, "Aspek-aspek primodialisme sangat potensial untuk dapat dimobilisasi ke dalam "politics of collective boundaries", dan memiliki potensi untuk menciptakan konflik di antara kelompok etnik". Untuk itu dibutuhkan toleransi antar umat beragama, saling menghormati, saling menghargai, yang dapat menciptakan nilai-nilai yang universal, yang mampu memberikan suasana harmonis di antara umat beragama sehingga dapat menciptakan kesatuan dalam keberagaman. Di mana ketika sekelompok orang tertekan dengan kondisi yang ada, dengan adanya dominasi dan stereotipe oleh pihak lain sehingga membentuk resistensi dan pemunculan identitas yang berbeda dari pihak yang mendominasi, yang dimunculkan oleh kelompok fundamentalis, revivalis, radikalis. Dengan semakin pesatnya arus transportasi dari dan keluar Kota Jayapura, tidak menutup kemungkinan berdatangan kelompok tersebut untuk mengganggu keutuhan persatuan masyarakat Kota Jayapura dalam kebinekaannya yang merupakan masyarakat yang multikulturalis.

\section{Mudah ditunggangi kelompok kepentingan}

Kelompok kepentingan (interest group) dalam masyarakat sangat menginginkan pencapaian sebuah tujuan kelompoknya. Demikian pula di Kota Jayapura, di mana terdapat suku, agama, ras, bahasa, dan budaya yang berbeda-beda sehingga rawan terhadap kecemburuan sosial dan mampu memunculkan gesekan antar warga yang mampu menimbulkan disintegrasi bangsa. Terlebih jika ditunggangi oleh kelompok-kelompok politik yang berseberangan dengan falsafah dan ideologi bangsa, hal ini disebabkan karena identitas keagamaan dapat menjadi fokus bagi mobilitas politik yang dimainkan oleh kelompok-kelompok tersebut. Tule dalam Parera \& Marzuki (2020) mengatakan, "Konflik antar umat beragama terjadi akibat munculnya simbol-simbol kegamaan yang dimanipulasi oleh kelompok-kelompok tertentu".

Munculnya simbol keagamaan Kristiani secara berlebihan, tanpa disadari muncul persepsi yang berbeda dalam masyarakat dan menimbulkan kecemburuan sosial, yang dapat ditunggangi kelompok kepentingan yang sengaja menjalankan misinya agar Jayapura memiliki nilai tawar tinggi di dunia internasional terutama Negara-negara yang mayoritas Kristiani, untuk mendapatkan akses dan dukungan baik materiil maupun formil, baik ekonomi, sosial, politik dari dunia luar, di mana dimunculkan persepsi bahwa Islam tidak banyak jumlahnya di Kota Jayapura, dari kondisi yang tidak ideal, dapat memunculkan konflik sosial di masyarakat khususnya yang ada di Kota Jayapura, ini diupayakan agar memunculkan anggapan rasa tidak aman di Kota Jayapura. Simbol keagamaan yang betebaran khususnya yang ada di Kota Jayapura, lambat laun dapat ditunggangi oleh kelompok revivalis/fundamentalis/radikalis, secara sengaja menghembuskan isu permusuhan di kalangan umat beragama, atau yang dilakukan oleh kelompok politik lainnya untuk menarik simpatik massa dengan cara yang tidak elegan, untuk memperoleh dukungan sebanyak-banyaknya dari orang yang awam dalam ilmu keagamaaan dan tidak paham dengan politik praktis, sehingga mudah dihasut dan terprovokasi dan mudah dipecah belah kerukunan umat beragamanya yang dapat menimbulkan konflik keagamaan, dan pada dasarnya adalah bukan kepentingan kelompok keagamaan, melainkan dimainkan kelompok politik, dan kelompok kepentingan lainnya yang dapat memecah belah persatuan dan kesatuan di kalangan umat beragama yang ada di Kota Jayapura, di mana antara Islam dan Kristen memiliki jumlah yang tidak jauh berbeda sehingga rentan tersulut dan mudah menimbulkan konflik. Dijelaskan Hannan (2018) mengatakan: "Bahasa agama dan ideologi memiliki kesamaan tentang hal menularkan pengaruhnya, sehingga keduanya sering kali bergerak dalam keterpaduan agar menghasilkan sitem dominatif yang sistematis". Di mana kelompok tersebut 
biasanya berada pada status sosial dan ekonomi yang ambivalen, terkadang tidak diindahkan oleh pemerintah, melakukan berbagai cara yang ditempuh untuk mengumpulkan kekuatan/massa dalam melakukan pressure terhadap pemerintah.

\section{Munculnya Diskriminasi Keagamaan}

Pembedaan kebebasan dalam penggunaan simbol-simbol keagamaan secara berlebihan oleh suatu kelompok keagamaan menimbulkan suatu bentuk diskriminasi yang mengerucut pada diskriminasi keagamaan. Tentu saja dari munculnya hal yang sepele seperti penggunaan simbol-simbol keagamaan akan berdampak dan merambat pada hal-hal lainnya yang lebih luas lagi yang berkaitan dengan keagamaan misalnya saja dunia pendidikan yang dikaitkan dengan agama, tenaga kerja yang dikaitkan dengan agama, dan masih banyak lagi hal-hal yang dapat dikaitkan dengan agama. Perlu ketegasan dari elemen pemerintah dalam penggunaan simbol keagamaan agar tidak berdampak pada sektor yang lebih luas. Masyarakat yang semakin berkembang menjadi egalitarian dan demokratis serta mempunyai keragaman budaya harus menempatkan harmonisasi sosial diatas ortodoksi keagamaan. Tentunya Kota Jayapura yang merupakan Kota yang heterogen dalam berbagai hal yang memiliki tingkat keragaman yang tinggi, hendaknya tidak terdapat diskriminasi di dalamnya terlebih yang berhubungan dengan masalah keagamaan.

Suprapto (2012, p. 25) mengatakan: "Pelanggaran pada aktivitas beragama dan berkeyakinan masih mewarnai wajah buruk hubungan antara mayoritas dan minoritas. Ironisnya, munculnya perlakuan diskriminatif ini justru dilakukan oleh Negara melalui penerbitan berbagai aturan yang pada akhirnya menjadi justifikasi oleh kelompok mayoritas untuk menekan kelompok minoritas. Terjadi diskriminasi keagamaan di Papua di mana Islam dianggap sebagai agama pendatang, dan untuk menempatkan diri sebagai kepala daerah sangat sulit diwujudkan, bukan hanya itu pemberian dukungan kepada setiap lembaga keagamaan secara proposional berdasarkan jumlah hanyalah omong kosong belaka, di mana pemberian bantuan keagamaan khususnya Islam hanya berharap dari Kementerian Agama RI, bantuan-bantuan yang jumlahnya kecil dari Pemda misalkan pada safari Ramadhan, sedangkan jika merujuk pada Undang-Undang Republik Indonesia Nomor 21 Tahun 2001 Tentang Otonomi Khusus Bagi Provinsi Papua (2001) yakni Pasal 54 d dan pasal 55 (1), maka Agama Islam memiliki kesempatan yang besar untuk mendapatkan bantuan dana umat dari pemerintah daerah.

\section{Pengawasan Terhadap Penggunaan Simbol Keagamaan}

Penggunaan simbol keagamaan Kristiani di Kota Jayapura jika tidak dilakukan pengawasan secara baik maka akan menimbulkan dampak negatif dari penggunaan simbol tersebut. Terlebih dalam hal memberikan pelayanan umum pada masyarakat terkait penggunaan simbol keagamaan yang bebas dan tidak memihak satu golongan saja, tanpa adanya diskriminasi dalam bentuk apapun yang dilakukan oleh pelayan masyarakat dalam hal ini pemerintah daerah, di mana diharapkan Pemerintah daerah dan kantor pemerintah lainnya berlaku netral pada setiap agama yang ada di Papua. Untuk itu dibutuhkan pengawasan yang mampu didukung oleh kebijakan yang baik. Pentingnya peran aktif pemerintah daerah dalam menjaga kestabilan politik di daerahnya, sehingga tercipta suasana aman, tentram, damai di wilayahnya tanpa adanya gangguan yang dapat membahayakan integritas bangsa di wilayahnya. Tidaklah salah pendapat Jurgen Hubermas yang dikutip Farhan (2019) yang mengatakan: "Ruang publik itu bersifat bebas, terbuka, transparan dan dijadikan penyampaian opini, kepentingan dan kebutuhan secara diskursif". Akan tetapi penggunaan simbol keagamaan yang dilakukan komunitas keagamaan di Kota Jayapura, hendaknya tidak bersifat diskriminatif dalam pengawasan yang dilakukan pemerintah daerah, hal ini akan berdampak pada kesenjangan sosial dan dapat memunculkan kecemburuan sosial di kalangan umat beragama dan akan memunculkan intoleransi beragama di Kota Jayapura.

Pengawasan dari pemerintah daerah secara adil dan bijaksana dalam penggunaan simbol keagamaan diharapkan dapat mengendalikan berbagai elemen keagamaan yang ada di Kota Jayapura dalam rangka penggunaan simbol keagamaan, sehingga penggunaannya dapat lebih terpantau agar 
tidak mengganggu komunitas keagamaan lainnya. Pengawasan yang dilakukan pemerintah daerah, dapat menghindarkan diri dari kecurigaan yang muncul akibat ketidakadilan yang dilakukan akibat dari penggunaan simbol keagamaan secara berlebihan yang dilakukan oleh sekelompok komunitas keagamaan yang mayoritas yang ada di Kota Jayapura, serta dapat mengendalikan seluruh perencanaan dalam rangka toleransi antar umat beragama yang ada di Kota Jayapura. Pengawasan yang baik dapat mengukur tingkat toleransi yang ada, sehinga pengetahuan tentang toleransi di Kota Jayapura bukan sekedar terkaan yang dimunculkan pandangan segelintir orang, dengan tekanan yang tinggi secara perlahan memunculkan gejolak di kalangan masyarakat.

\section{Kontestasi Simbol Keagamaan Kristiani}

\section{Kebebasan dalam penggunaan simbol keagamaan}

Simbol keagamaan mulai merebak sejak masuknya agama samawi di Papua. Ini dapat dilihat sejak masuknya agama Kristiani yang dibawa Zending dan Misionaris, maka mulai bermunculan simbolsimbol kristiani, seperti salib, bintang Daud dan pohon natal. Para Zendeling tiba di Mansinam Papua Barat oleh Ottow dan Geisller, kemudian bergerak ke ujung Timur sampai di wilayah Jayapura. Sedangkan umat Islam kemunculannya dibawa oleh pedagang Bugis, Makasar, Buton, serta kesultanan Ternate dan Tidore yang pada saat itu kekuasaannya mencapai Kota Jayapura. Misionaris lebih berkembang pesat diwilayah Selatan Papua seperti wilayah Marauke, dan Timika sedangkan Zending lebih berkembang di wilayah Utara Papua mulai dari Manokwari, Sorong, Biak, Serui, Nabire dan Jayapura, sampai wilayah Pegunungan, sedangkan Islam pada saat itu lebih berkembang di wilayah Barat Papua, yaitu wilayah Raja Ampat, Fak-fak, Kaimana dan daerah pesisir pantai bagian Barat lainnya, sehingga pesatnya penyebaran agama Kristen di wilayah Papua tidak dapat ditandingi oleh agama manapun termasuk Islam.

Saat ini perkembangan Islam hampir menyamai agama Kristen di Papua, dengan banyaknya kaum urban yang melakukan migrasi dari daerah asalnya ke Papua, ditunjang tingginya moda transportasi dari dan ke luar Papua. Pada masa orde baru penggunaan simbol keagamaan merata bagi umat Muslim dan umat Kristiani di Kota Jayapura, dan dirasakan tidak seperti sebuah kontestasi, di mana keduanya memiliki jumlah pengikut cukup banyak, bahkan dapat dikatakan saat itu jumlah umat Muslim masih sedikit dan kehidupan beragama sangat baik serta toleransi keagamaan sangat kental, jarang terjadi persinggungan antar agama, juga penggunaan simbol keagamaan cukup berimbang. Namun saat ini penggunaan simbol keagamaan meresahkan warga yang bukan beragama Kristiani, kebebasan yang dimiliki oleh umat Non Kristiani tidak sama dengan yang beragama Kristiani, kelompok Kristiani mengerahkan kekuatan simbolnya ketimbang agama lain, dengan berbagai simbol keagamaannya mulai dari Salib, bintang Daud, pohon Natal, lukisan Yesus Kristus, pondok Natal, sampai dengan Santa Claus terpampang di mana-mana, bahkan simbol tersebut juga dalam bentuk ceramah keagamaan yang dilakukan disembarang tempat. Hal tersebut sejalan dengan apa yang dikatakan oleh Mulyana yang dikutip Hutapea (2017) mengatakan: "Simbol itu memiliki variasi dari satu waktu ke waktu yang lain". Sehingga dapat dikatakan bahwa gambaran Kota Jayapura tentang penggunaan simbol keagamaan dahulu dan saat ini sangat berbeda. Kebebasan penggunaan simbol keagamaan yang dilakukan umat Kristiani di Kota Jayapura terasa meresahkan, dilihat dari banyaknya simbol terpasang secara permanent maupun non permanen. Penggunaan simbol bukan hanya saat menyambut hari besar keagamaan, namun setelah dilaksanakan hari besar simbol-simbol dibiarkan terpasang kecuali yang secara permanent sudah tidak mungkin lagi untuk dilepaskan. Pemasangan simbol dilakukan bukan hanya ditempat umum, juga ditempat sunyi yang jarang dilalui orang terkadang terdapat simbol keagamaan Kristiani.

Kebebasan penggunaan simbol keagamaan di Kota Jayapura yang dilakukan kelompok keagamaan tertentu, di mana bentuk simbol keagamaan baik dalam kata-kata, isyarat, lukisan, bunyi musik, peralatan hendaknya memiliki aturan dalam penggunaannya yang dapat ditetapkan oleh pemerintah daerah, dan tidak diskriminatif dalam penggunaannya yang hanya dikuasai satu kelompok keagamaan dan terkesan kebablasan walaupun unsur simbolik dalam kehidupan nyata 
mempunyai kecenderungan berjalan liar, tetapi adanya aturan dapat menjaga stabilitas keamanan, ketertiban, dan memperkecil munculnya konflik di antara umat beragama.

Yang mayoritas dan minoritas dalam agama

Pesatnya pembangunan di berbagai sektor, terutama arus transportasi yang semakin lancar, mampu menyumbang percepatan pembangunan sehingga sektor lainnya mampu bergerak lebih cepat, menyebabkan Kota Jayapura memiliki tingkat heterogenitas yang tinggi dari masyarakatnya, baik suku, ras dan agama. Hal ini seperti yang diungkapkan Wirman, (2017) yang mengatakan: Masyarakat plural terdiri atas berbagai kelompok, budaya, etnis serta agama. Pluralisme adalah keberagaman masyarakat akan tetapi hidup memiliki satu kesatuan dalam kehidupan sosial tanpa intimidasi dari kelompok mayoritas pada kelompok minoritas (Rahman \& Setia, 2021). Begitu pula dengan komunitas keagamaan yang ada di Kota Jayapura yang cukup beragam, mulai dari kelompok mayoritas Protestan, disusul Muslim, Katholik, Hindu, dan Buddha (tabel 1). Sekat antara mayoritas dan minoritas mulai terasa ketika munculnya UU otonomi khusus yang digelontorkan untuk mengatur kehidupan masyarakat baik pribumi maupun non pribumi di Papua dalam menjalankan kehidupan bermasyarakat.

Tabel 1 Jumlah Penduduk Kota Jayapura Berdasarkan Agama

\begin{tabular}{|c|c|c|c|c|c|}
\hline \multicolumn{5}{|c|}{ Agama } & Total \\
\hline $\begin{array}{c}\text { Kristen } \\
\text { Katholik }\end{array}$ & $\begin{array}{c}\text { Kristen } \\
\text { Protestan }\end{array}$ & Islam & Hindu & Buddha & \\
\hline 84.474 & 283.493 & 254.100 & 2.097 & 2.370 & 626.534 \\
\hline
\end{tabular}

Sumber Data: Kantor Statistik Kota Jayapura Tahun 2019.

Alokasi keuangan yang terkait pembangunan dibidang keagamaan dilihat dari jumlah umat beragama. Bermunculan organisasi yang membedakan antara pribumi dan non pribumi yang secara tidak langsung mempersempit ruang gerak kelompok non pribumi yang mayoritasnya adalah umat Islam. Islam yang menempati posisi kedua di Kota Jayapura, dalam kenyataannya tetap pada posisi ketiga setelah Kristen Katholik, di mana perwakilan Islam dalam berbagai hal misalnya Majelis Rakyat Papua (MRP) hanya menempati 1 kursi saja di Tahun 2019. Demikian pula anggota DPRD Kota Jayapura, yang pada Pemilihan Anggota Legislatif (Pileg) Kota Jayapura tahun 2014-2019 hanya meraih 11 kursi (35\%) untuk yang beragama Islam dari 40 kursi yang tersedia yang lebih mirisnya lagi di tahun yang sama untuk daerah pemilihan 4 Wilayah Abepura hanya memperoleh 1 kursi yang beragama Islam dari 12 kursi yang diperebutkan, padahal jumlah umat Islam cukup banyak di DAPIL tersebut, sedangkan untuk Pileg 2019-2024 mengalami kenaikan yaitu 16 orang (35,5\%) yang beragama Islam dengan jumlah kursi yang diperebutkan sebanyak 45. Hal ini menimbulkan pertanyaan, bagaimana mungkin mampu menyuarakan aspirasi umat Islam yang ada di Kota Jayapura, terlebih di beberapa Distrik dengan jumlah umat Islam yang banyak, namun tidak mampu menyatukan umat Islam yang ada.

Terjadi degradasi nilai harmonisasi keagamaan antar umat beragama di Kota Jayapura, terutama antara komunitas Islam dan Kristen, karena munculnya organisasi lokal yang mampu membuat keputusan yang mempengaruhi tatanan hidup beragama masyarakat Kota Jayapura dan berimbas pada pemakzulan keputusan tersebut oleh Pemda Kota Jayapura, di mana keputusan tersebut suka tidak suka harus dipatuhi oleh warganya. Di mana organisasi tersebut dikuasai warga pribumi sebagai pengejawantahan Undang-undang Otsus Tahun 2001 di mana masyarakat pribumi mayoritas beragama Kristiani, sehingga untuk menyuarakan aspirasi umat Islam tidak dapat terealisir. Muatan politik lokal mempengaruhi kebijakan yang diambil, sehingga merugikan kelompok minoritas, karena keputusan tersebut bukan secara penuh bercirikan tingkahlaku pelaksana keputusan yaitu umat Islam, 
melainkan secara sepihak dibuat, dipaksakan menjadi keputusan tetap yang harus dilaksanakan tanpa adanya filter yang menyaring dan meredam segala bentuk diskriminasi.

\section{Keseimbangan penggunaan simbol masing-masing agama}

Penggunaan simbol keagamaan dirasakan saat ini tidak berimbang antara satu agama dengan agama lainnya di Kota Jayapura. Kelompok mayoritas lebih mengungguli kelompok minoritas dalam penggunaan simbol keagamaan. Ini berakibat pada ruang yang sempit bagi kelompok minoritas mengembangkan atau menjadi penyeimbang bagi yang mayoritas dalam hal penggunaan simbol keagamaan. Penekanan simbol keagamaan minoritas sangat dirasakan hanya pada saat memperingati hari besar keagamaan, setelahnya harus segera dicabut dan tidak boleh berlama-lama terpasang, kecuali yang terpasang pada basis keagamaan, seperti Sekolah yang berbasis Islam atau yang ada pada Masjid.

Ketidakadilan penggunaan simbol keagamaan di Kota Jayapura, di mana Pemda tidak memberikan kebebasan secara adil terhadap penggunaan simbol keagamaan yang ada, sehingga makna dari simbol yang dimunculkan pada peringatan hari Raya tidak terasa bagi kaum minoritas, di mana pelaksanaan hari raya tanpa adanya kemeriahan yang sebenarnya merupakan bentuk simbolisme agama, untuk itu dibutuhkan keadilan yang sama dalam pelaksanaannya sehingga memperkecil diskriminasi penggunaan simbol keagamaan. Ketidakadilan sangat nyata ketika melihat berbagai simbol keagamaan Kristiani yang secara permanen dibuat di berbagai sudut Kota Jayapura, dan jarang dijumpai simbol keagamaan Islam atau agama lainnya, yang dibuat secara permanen. Tanpa disadari bahwa penggunaan simbol keagamaan secara berlebihan merupakan bentuk dari pressure bagi kelompok minoritas keagamaan.

Simbol merupakan identitas seseorang atau sekelompok orang dan memiliki kekuatan di mana kelompok itu berada. Perlu pembinaan dan himbauan terus menerus oleh pemerintah pusat pada tokoh agama, tokoh masyarakat, pemimpin lembaga pemerintahan daerah, agar tidak mengesampingkan kelompok keagamaan minoritas, sehingga setiap kelompok keagamaan mampu menghormati dan menghargai dalam penggunaan simbol keagamaan tanpa membedakan kelompok keagamaan dalam penggunaan simbol. Adanya pembatasan penggunaan simbol keagamaan secara adil dan bijak, hendaknya mampu direalisasikan dalam kehidupan nyata seperti halnya di Kota Jayapura, sehingga timbul keseimbangan penggunaan simbol keagamaan, dan toleransi antar umat beragama dapat tercipta tanpa adanya tekanan dari segenap pihak.

\section{Maraknya simbol Kristiani di berbagai sudut Kota}

Penggunaan simbol keagamaan yang berlebihan dapat menimbulkan intoleransi antar umat beragama, di mana antipati muncul terhadap komunitas keagamaan tertentu yaitu orang di luar pengguna simbol akibat adanya diskriminasi yang dilakukan. Agama Protestan merupakan agama terbesar di Kota Jayapura, dan merupakan agama terbesar kaum pribumi, akhir-akhir ini sering menggunakan simbol keagamaan secara besar-besaran dan berlebihan, di mana simbol tersebut terpampang di berbagai sudut Kota tanpa adanya pembatasan, melainkan memperoleh dukungan kuat dari Pemda Kota Jayapura. Simbol Kristiani bukan hanya mewakili umat Protestan, tetapi juga mewakili umat Katholik yang ada. Pemasangan simbol keagamaan Kristiani yang ada di Kota Jayapura bukan hanya ditempat yang ramai penduduk atau yang sering dilalui masyarakat, juga dipasang ditempat yang tidak berpenghuni seperti halnya di atas gunung, pulau, di jalan protokol maupun di gang-gang, dari ukuran kecil sampai ukuran besar sehingga mampu dilihat dari kejauhan oleh orang yang melintasinya.

Terdapat monopoli dalam penggunaan identitas simbol keagamaan yang dilakukan kelompok mayoritas keagamaan yang ada di Kota Jayapura dalam hal ini umat Kristiani, di mana dengan simbol yang terpasang, berusaha untuk menunjukkan tentang kemayoritasannya dan superioritasnya, hal ini muncul akibat peniruan yang dilakukan kelompok mayoritas keagamaan di daerah lainnya yang ada di Indonesia, dengan jalan meniru berbagai pola yang terjadi di daerah lain dan menerapkannya di Kota Jayapura, yang sengaja digunakan untuk menyatukan komunitas keagamaan dengan 
mengembangkan berbagai simbol keagamaannya di Kota Jayapura sehingga nampak mereka memiliki ikatan dan kesatuan yang kuat dan besar melebihi kelompok keagamaan lainnya dan memiliki pengaruh kuat yang mampu merubah, mempengaruhi kebijakan yang muncul dalam mengatur tatanan kehidupan bermasyarakat. Seperti yang diungkapkan Maliki dikutip Zainuddin (2013, p. 3) yang mengatakan: "Pada ruang publik, agama digunakan oleh elit penguasa lokal untuk sumberdaya politik atau alat mengembangkan legitimasi kekuasaan melalui berbagai cara sesuai ritme dan konteks sosial yang sedang dihadapi". Penekanan yang dilakukan kelompok mayoritas dengan menggunakan simbol keagamaan kepada kelompok minoritas lainnya, sehingga bermunculan berbagai simbol keagamaan di berbagai tempat dari satu kelompok keagamaan untuk menunjukkan jati diri dan eksistensinya serta mengklaim sebagai yang terbesar.

\section{Kesimpulan}

Munculnya berbagai bentuk simbol keagamaan yang digunakan oleh umat Kristiani di Kota Jayapura di berbagai ruang publik tanpa adanya pembatasan yang menimbulkan sebuah kontestasi simbol keagamaan, untuk menunjukkan kebesaran suatu kelompok keagamaan. Bentuk simbol keagamaan Kristiani yang ada di Kota Jayapura memiliki arti dan makna tersendiri dari setiap simbol serta merupakan wahana yang dapat ditafsirkan oleh pengikutnya, diharapkan memberikan nilai religius dan merupakan identitas yang memiliki peran penting bagi kelompok keagamaan. Penggunaan simbol keagamaan dilakukan secara terencana, terkoordinir, dan terstruktur, membentuk jaringan kognitif dari skema tindakan yang terkoordinasi, untuk menarik simpatik masyarakat yang memiliki kesamaan keimanan untuk bersatu menampakkan kebesaran. Fatwa MUI tentang pelarangan penggunaan simbol agama lain akan berpengaruh bagi aktifitas umat Muslim di Indonesia, satu sisi merupakan kepentingan pemilik toko untuk menarik pembeli tentang penggunaan simbol, tetapi dapat membahayakan jika tidak disikapi secara bijaksana. Pesatnya transportasi dari dan keluar Kota Jayapura menyebabkan berdatangan kelompok radikalis untuk mengganggu persatuan masyarakat Kota Jayapura. Simbol keagamaan Kristiani secara berlebihan dapat ditunggangi kelompok kepentingan yang menjalankan misi agar Jayapura memiliki nilai tawar di dunia internasional terutama negara-negara yang mayoritas Kristiani untuk mendapatkan dukungan, dengan persepsi Islam sedikit jumlahnya di Kota Jayapura. Simbol keagamaan dapat ditunggangi berbagai kelompok politik untuk memperoleh dukungan dari orang yang awam politik praktis, sehingga mudah dihasut dan terprovokasi dan mudah dipecah belah, di mana antara Islam dan Kristen memiliki jumlah yang tidak jauh berbeda sehingga rentan tersulut konflik. Di Papua Islam dianggap sebagai agama pendatang, untuk menempatkan diri sebagai Kepala Daerah sulit diwujudkan. Muatan politik lokal mempengaruhi kebijakan keagamaan yang diambil sehingga merugikan kelompok minoritas. Terdapat monopoli penggunaan identitas simbol keagamaan oleh kelompok mayoritas, muncul akibat peniruan yang dilakukan kelompok mayoritas keagamaan di daerah lain, dengan meniru pola dan menerapkannya di Kota Jayapura, yang digunakan untuk menyatukan komunitas keagamaannya, mengembangkan simbol keagamaannya sehingga nampak memiliki ikatan dan kesatuan yang kuat dan klaim sebagai yang terbesar melebihi kelompok keagamaan lainnya dan memiliki pengaruh kuat yang mampu mempengaruhi kebijakan yang muncul.

Diperlukan pengawasan oleh pemerintah pusat terhadap produk perundang-undangan yang digulirkan, agar tidak merugikan kelompok minoritas yang ada di Papua. Dibutuhkan keadilan yang diberikan Pemda Kota Jayapura dalam penggunaan simbol keagamaan, dengan jalan membuat lahan khusus untuk menempatkan berbagai simbol keagamaan agar dapat lebih tertata. Adanya persatuan di kalangan umat Islam untuk menyatukan persepsi dalam penentuan wakilnya di DPRD maupun MRP agar dapat mengantisispasi dan meredam berbagai kemungkinan kebijakan yang merugikan umat Islam. Dibutuhkan berbagai sosialisasi dari pemerintah pusat terhadap pemimpin di daerah, baik pimpinan pemerintahan, tokoh masyarakat dan tokoh agama untuk meredam berbagai kemungkinan gejolak yang dapat muncul akibat penggunaan simbol-simbol keagamaan secara berlebihan. Penggunaan simbol keagamaan secara berlebihan yang telah berlangsung cukup lama merupakan sebuah realita yang ada di Kota Jayapura, sehingga dibutuhkan penelitian lebih lanjut yang 
memfokuskan pada kekuatan simbol dalam mempengaruhi tatanan kehidupan keagamaan dan politik di Kota Jayapura.

\section{Referensi}

Bataona, M. R., \& Bajari, A. (2017). Relasi kuasa dan simbol ekonomi-politik gereja dalam kontestasi politik lokal Provinsi NTT. Jurnal Kajian Komunikasi, 5(2), 121-135. https://doi.org/10.24198/jkk.v5i2.8831

Buchari, S. A. (2014). Kebangkitan etnis menuju politik identitas. Jakarta: Yayasan Pustaka Obor Indonesia.

Castells, M. (2011). The power of identity (Vol. 14). New York: John Wiley \& Sons.

Denzin Yvonna S., N. K. . L. (2009). Handbook of Qualitative Research. California, USA: Sage Publications.

Dillistone, F. W. (2002). The Power of Symbols. Yogyakarta: Kanisius.

Ernas, S. (2015). Politik simbol dan harmoni sosial: Makna satu tungku tiga batu dalam dinamika politik lokal di Fakfak, Papua Barat. Dialektika, 9(2), 1-18.

Faisal, F., Mulkhan, A. M., Nurmandi, A., \& Jubba, H. (2019). From Conflict to Assimilation: Strategies of Muslim Immigrants in Papua Special Autonomy Era. Wawasan: Jurnal Ilmiah Agama Dan Sosial Budaya, 4(1), 103-116.

Farhan, F. I. (2019). Komodifikasi Agama Dan Simbol Keagamaan 'Jilbab' Di Media Online Dalam Persepsi Netizen. AT-TAHDZIB: Studi Islam Dan Muamalah, 7(1), 51-69.

Ghazali, A. M. (2011). Antropologi Agama: Upaya Memahami Keragaman Kepercayaan, Keyakinan, dan Agama. Bandung: Alfabeta.

Hannan, A.-. (2018). Agama, Kekerasan, dan Kontestasi Politik Elektoral: Penggunaan Simbol Keagamaan Kiai dan Kekuasaan Blater dalam Pertarungan Politik Lokal Madura. Jurnal Sosiologi Agama, 12(2), 187-222. https://doi.org/10.14421/jsa.2018.187-222

Hasbullah, H. (2011). Agama dan Etnisitas di Pentas Politik Lokal (Tinjauan Terhadap Penggunaan Simbol Agama dan Etnis dalam Pilkada). Jurnal Ushuluddin, 17(2), 170-182.

Hutapea, E. (2017). Identifikasi Diri Melalui Simbol-Simbol Komunikasi (Studi Interaksionisme Simbolik Komunitas Pemakai Narkoba di DKI Jakarta). Bricolage: Jurnal Magister Ilmu Komunikasi, 2(1), 1-14.

Iribaram, S., Abdullah, I., \& Pribadi, U. (2018). Diskriminasi Muslim dalam Birokrasi Studi pada Pemerintahan Kota Jayapura. Al-Ulum, 18(1), 107-126. https://doi.org/10.30603/au.v18i1.363

Jubba, H., Abdullah, I., Pabbajah, M., Iribaram, S., Prasojo, Z. H., \& Qodir, Z. (2020). The display of religious symbols in public space: The contestation of muslim and christian identities in jayapura, Papua. Humanities and Social Sciences Reviews, 8(1), 642-650. https://doi.org/10.18510/hssr.2020.8177

Lutfi, A. (2019). Praktik-Praktik Kebenaran Agama Analisis Kontestasi Komunitas Muslim di Hadapan Katolik di Ponorogo. Jurnal Masyarakat Dan Budaya, 21(1), 17-30. https://doi.org/10.14203/jmb.v21i1.641

Nawir, M. S., Yusuf, M., \& Kadir, A. (2020). Islam Raja Ampat dan Mitos Hantu Cuwig : Benturan Agama , Adat dan Kepercayaan Lokal pada Masyarakat Multikultural di Kampung Lilinta Papua Barat. SANGKEP: Jurnal Kajian Sosial Keagamaan, 3(1), 1-22. https://doi.org/10.20414/sangkep.v2i2.p-ISSN

Pals, D. L. (2012). Seven Theories of Religion: Tujuh Teori Agama Paling Komprehensif. Yogyakarta: IRCiSoD.

Parera, M. M. A. E., \& Marzuki, M. (2020). Kearifan Lokal Masyarakat dalam Membangun Kerukunan Umat Beragama di Kota Kupang, Nusa Tenggara Timur. Jurnal Antropologi: Isu-Isu Sosial Budaya, 22(1), 38-47.

Presiden Republik Indonesia. (2001). Undang-Undang Republik Indonesia Nomor 21 Tahun 2001 Tentang Otonomi Khusus Bagi Provinsi Papua.

Qodir, Z. (2015). Kontestasi Penyiaran Agama di Ruang Publik: Relasi Kristen dan Islam di Kota Jayapura. Harmoni, 14(1), 38-52.

Rahman, M. T., \& Setia, P. (2021). Pluralism in the Light of Islam. Jurnal Iman Dan Spiritualitas, 1(2), 204=210. https://doi.org/http://dx.doi.org/10.15575/jis.v1i2.12269

Ritzer, G., \& Goodman, D. J. (2012). Teori Sosiologi Modern. In Yogyakarta: Kreasi Wacana. Yogyakarta: Kreasi Wacana.

Samovar, L. A., Porter, R. E., Stefani, L. A., \& Sidabalok, I. M. (2010). Komunikasi lintas budaya. Jakarta: Salemba Humanika.

Saprillah, S., Juhannis, H., Said, N., \& Al-Rasyid, H. H. (2020). Kontestasi Keagamaan dalam Masyarakat Muslim Urban. Al-Qalam, 26(1), 39-56. https://doi.org/10.31969/alq.v26i1.844

Sari, L. M. (2018). Simbol Salib dalam Agama Kristen. Religi: Jurnal Studi Agama-Agama, 14(2), 155-168.

Setyawati, L. (2010). Keberagaman dan Eksklusi Sosial: Simbol Identitas dalam Ruang Publik. Jurnal Masyarakat Dan Budaya, 12(3), 117-136.

Solikhati, S. (2018). Simbol Keagamaan Dalam Islam dan Ideologi Televisi. Islamic Communication Journal, 2(2), 121146.

Suprapto, S. (2012). Membina Relasi Damai Antara Mayoritas dan Minoritas (Telaah Kritis atas Peran Negara dan 
Umat Islam dalam Mengembangkan Demokrasi di Indonesia). Analisis: Jurnal Studi Keislaman, 12(1), 19-48. Turner, B. S. (2012). Teori Sosiologi dari Klasik sampai Postmodern. Yogyakarta: Pustaka Pelajar.

Wirman, W. (2017). Plurality in The Context of Religious Harmony. IOSR Journal of Humanities and Social Science, 22(11), 25-31.

Zainuddin, M. (2013). Haji dan Status Sosial: Studi Tentang Simbol Agama di Kalangan Masyarakat Muslim. ElHARAKAH, 15(2), 169-184.

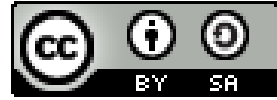

(C) 2021 by the authors. Submitted for possible open access publication under the terms and conditions of the Creative Commons Attribution (CC BY SA) license (https://creativecommons.org/licenses/by-sa/3.0/). 